\title{
DINAMIKA DAN PARTISIPASI ANGGOTA KELOMPOK WANITA TANI DALAM PROGRAM DIVERSIFIKASI OLAHAN PANGAN FUNGSIONAL DI DESA JIMBARAN, MARGOREJO, PATI
}

\author{
Jamiatun $^{1 *}$, Dwi Putri Jeng Ivo Nurunnisa, ${ }^{1}$, Nurul Wahidah Rahmatika ${ }^{2}$, Abida \\ Choirul Mar'ati ${ }^{2}$, Salwa Al Aribah ${ }^{3}$, Eksa Rusdiyana ${ }^{3}$ \\ ${ }^{1}$ Mahasiswa Program Studi Agribisnis; ${ }^{2}$ Mahasiswa Program Studi Penuluhan dan \\ Komunikasi Pertanian $;{ }^{3}$ Mahasiswa Program Studi Ilmu dan Teknologi Pangan; ${ }^{4}$ Staff \\ Pengajar Program Studi Penyuluhan dan Komunikasi Pertanian \\ Fakultas Pertanian Universitas Sebelas MaretSurakarta \\ *Email: atunjami32@gmail.com
}

\begin{abstract}
ABSTRAK
Kegiatan pemberdayaan dilakukan di Desa Jimbaran, Margorejo, Pati. Metode yang digunakan yaitu penyuluhan, pelatihan pembuatan produk pangan fungsional berbasis ubi kayu dan bandeng, dan pendampingan IPTEK. Target luaran yang diharapkan adalah meningkatkan pengetahuan dan keterampilan masyarakat sasaran serta terciptanya produk unggulan berbasis olahan pangan ampas ubi kayu dan bandeng. Dari kegiatan ini, diperkenalkan tiga macam produk yaitu BAKAMBU (bakso ampas ubi kayu dan bandeng), PUKEPO (pudding ketela pohon), dan DOKEPO (donat ketela pohon) aneka rasa. Bentuk-bentuk pemberdayaan masyarakat yang dilakukan melibatkan partisipasi masyarakat mulai dari perencanaan, pelaksanaan dan evaluasi. Penelitian ini bertujuan untuk mengetahui dinamika dan partisipasi anggota Kelompok Wanita Tani (KWT) Wijaya Kusuma dalam program diversifikasi olahan pangan berbasis potensi ubi kayu dan bandeng. Penelitian ini merupakan penelitian deskriptif yang berusaha menguraikan masalah yang diteliti. Hasil pemberdayaan menunjukkan bahwa dinamika anggota KWT selama program berlangsung dinamis dan tingkat partisipasi berada pada kategori aktif. Pemberdayaan masyarakat melalui diversifikasi pangan lokal berbasis ubi kayu dan bandeng memberikan manfaat berupa terciptanya lingkungan masyarakat yang terbebas dari limbah ampas ubi kayu, terciptanya lapangan pekerjaan, dan meningkatkan pendapatan masyarakat.
\end{abstract}

Kata kunci: pemberdayaan masyarakat, pangan fungsional, ubi kayu, bandeng

\section{PENDAHULUAN}

Ikan bandeng merupakan salah satu jenis ikan yang banyak dikonsumsi oleh masyarakat Indonesia karena mempunyai rasa daging yang enak dan harga yang terjangkau. Ikan bandeng berpotensi untuk meningkatkan gizi masyarakat di Indonesia. Ikan tersebut termasuk komoditas perikanan yang relatif mudah dibudidayakan dan teknologinya mudah diterapkan di masyarakat, memiliki nilai pilihan konsumen yang tinggi, serta tahan terhadap perubahan lingkungan yang ekstrim.

Kabupaten Pati merupakan salah satu sentra produksi ikan bandeng terbesar di Provinsi Jawa Tengah. Berbagai permasalahan pun juga ikut berkembang, seperti pada kontinuitas produksi, pemasaran hasil, serta aspek lingkungan. Perlunya sentuhan mengenai proses pemasaran hasil produksi ikan bandeng tersebut untuk meningkatkan daya tarik dalam pemasaran hasil produksinya. Sentuhan-sentuhan ini akan memperluas pemasaran dan menambah pendapatan karena adanya diversifikasi 
pangan sehingga Kabupaten Pati mempunyai potensi besar dalam mengembangkan produk baru hasil diversifikasi pangan.

Kabupaten Pati selain terkenal dengan produksi ikan bandengnya juga terkenal dengan produksi ubi kayu. Ubi kayu atau sering disebut singkong merupakan produk lokal Kabupaten Pati yang jumlahnya sangat melimpah terutama di daerah kawasan Jimbaran, Kecamatan Margorejo. Masyarakat menjadikan ubi kayu sebagai salah satu mata pencahariannya karena sangat potensial untuk ditanam. Berdasarkan data dari Badan Pusat Statistik Kabupaten Pati (2014) produksi ubi kayu di daerah Kabupaten Pati mengalami kenaikan setiap tahunnya.

Ubi kayu memiliki beberapa manfaat untuk kesehatan. Menurut Wijayakusuma (2010) efek farmakologis dari ubi kayu adalah sebagai antioksidan, antikanker, antitumor, dan menambah nafsu makan. Ubi kayu mengandung kalori, protein, lemak, hidrat arang, kalsium, fosfor, zat besi, vitamin $\mathrm{B}$ dan $\mathrm{C}$, serta amilum. Tidak banyak yang tahu bahwa ampas ubi kayu yang biasanya sebagi pakan ternak memiliki potensi untuk dijadikan sebagai pengganti bahan pangan pokok. Selama ini ubi kayu hanya diolah menjadi tepung tapioka dan menghasilkan sisa limbah padat berupa ampas ubi kayu. Limbah ubi kayu apabila tidak ditangani secara tepat dapat menyebabkan pencemaran lingkungan baik bagi tanah, udara, maupun air. Oleh karena itu diperlukaan upaya kerjasama untuk mengatasi berbagai permasalahan di atas.

Permasalahan ampas ubi kayu dan bandeng dapat diselesaikan dengan beragam cara salah satunya yaitu dengan memberdayakan kelompok masyarakat melalui diversifikasi pangan fungsional berbahan dasar ampas ubi kayu dan bandeng. pengembangan pengolahan hasil potensi setempat.
Tujuan dari pemberdayaan ini adalah untuk mengetahui dinamika dalam program pemberdayaan diversifikasi pangan berbasis olahan ampas ubi kayu dan bandeng sehingga mampu meningkatkan pengetahuan dan keterampilan Kelompok Wanita Tani (KWT) Wijaya Kusuma. Pemberdayaan masyarakat melalui diversifikasi pangan lokal berbasis ubi kayu dan bandeng memberikan manfaat berupa terciptanya lingkungan masyarakat yang terbebas dari limbah ampas ubi kayu, terciptanya lapangan pekerjaan, dan meningkatkan pendapatan masyarakat.

\section{KEGIATAN DAN METODE PENGABDIAN}

Adapun kegiatan yang direncanakan meliputi: survey awal untuk mengetahui tingkat pengetahuan mitra, kondisi lingkungan dan proses perijinan; kooordinasi dengan mitra untuk menentukan waktu, tempat pelaksanaan serta materi yang dibutuhkan mitra; penyiapan peralatan dan perlengkapan pelatihan; sosialisasi dan praktek pembuatan pukepo (pudding ketela pohon), dokepo (donat ketela pohon), dan bakambu (bakso ampas ubi kayu dan bandeng).

Survei awal dilakukan dengan wawancara yang dilakukan oleh peneliti yang bersifat terbuka. Partisipan yang dipilih dalam pengumpulan data melalui wawancara adalah orang yang dianggap tahu tentang proses pemberdayaan masyarakat di Desa Jimbaran, Margorejo, Pati sehingga mereka dapat memberikan masukan secara tepat tentang potensi, kendala dan strategi pengembangan potensi di desa tersebut. Partisipan yang dipilih sebanyak 3 orang yaitu Kepala Desa Jimbaran, Ketua Kelompok Wanita Tani (KWT) Wijaya Kusuma Desa Jimbaran, dan anggota Kelompok Wanita Tani (KWT) Wijaya Kusuma Desa Jimbaran.

Data sekunder diperoleh dari studi kepustakaan yaitu pengumpulan data dari 
sejumlah literatur berupa buku, jurnal, majalah, koran ataupun karya tulis lainnya yang relevan dengan topik penelitian, dokumentasi, memanfaatkan dokumen tertulis, gambar maupun berbentuk karya yang berkaitan dengan aspek-aspek yang diteliti dan data dari internet. Metode analisis data meliputi pengumpulan data, reduksi data, penyajian data dan pengambilan kesimpulan.

\section{HASIL DAN PEMBAHASAN}

\section{Profil Kelompok Wanita Tani (KWT) Wijaya Kusuma}

Berdasarkan kuisioner yang telah diberikan kepada 21 peserta yang merupakan pengurus dan anggota dari Kelompok Wanita Tani (KWT) dapat diketahui profilnya berdasarkan tingkat usia sebagai berikut.

Profil Kelompok Wanita Tani (KWT) Wijaya Kusuma Berdasarkan Tingkat Usia

Tabel 1. Profil Kelompok Wanita Tani (KWT) Wijaya Kusuma

\begin{tabular}{ccc}
\hline $\begin{array}{c}\text { Usia } \\
\text { (Tahun) }\end{array}$ & Banyaknya & $\begin{array}{l}\text { Persentase } \\
(\boldsymbol{\%})\end{array}$ \\
\hline $25-38$ & 7 & 33.33 \\
$39-52$ & 8 & 38,10 \\
$53-65$ & 6 & 28,57 \\
Jumlah & 21 & 100,00 \\
\hline
\end{tabular}

Sumber: Data Primer, 2018

Berdasarkan tabel 1 dapat diketahui bahwa penilaian sebagian besar responden terhadap tingkat usia beragam yang dibagi menjadi 3 golongan yaitu usia 25-38, 39-52, dan 53-65. Kelompok Wanita Tani (KWT) Wijaya Kusuma Desa Jimbaran, Margorejo, Pati paling banyak berusia di antara 39 sampai dengan 52 tahun dengan jumlah 8 orang. Sedangkan sisanya berumur diantara 25 sampai dengan 38 tahun sebanyak 7 orang dan yang berusia 53 sampai dengan 65 tahun sebanyak 6 orang. Banyaknya umur produktif yang mengikuti program pelatihan ini menyebabkan tingginya antusias wanita tani.
Profil Kelompok Wanita Tani (KWT) Berdasarkan Tingkat Pendidikan

Profil Kelompok Wanita Tani (KWT) Wijaya Kusuma Berdasarkan tingkat pendidikan dibagi menjadi 5 golongan yaitu tidak tamat SD, SD, SMP, SMA, dan sarjana. Dari 21 responden terdapat 2 orang yang tidak lulus SD, sebanyak 6 orang menempuh pendidikan SD, sebanyak 3 orang menempuh pendidikan SMP, 8 orang menempuh pendidikan SMA, dan sebanyak 2 orang yang menempuh pendidikan sampai sarjana.

Tabel 2. Profil KWT Berdasarkan

Tingkat Pendidikan

\begin{tabular}{ccc}
\hline Jenjang & Jumlah & $\begin{array}{c}\text { Persentase } \\
(\mathbf{\%})\end{array}$ \\
\hline Tidak Tamat SD & 2 & 9,5 \\
SD & 6 & 28,6 \\
SMP & 3 & 14,3 \\
SMA & 8 & 38,1 \\
Sarjana & 2 & 9,5 \\
Jumlah & 21 & 100,0 \\
\hline
\end{tabular}

Sumber: Data Primer, 2018

Kondisi ini sangat memprihatinkan karena di era sekarang ini pendidikan menjadi hal yang sangat pening untuk mengukur tingkat keterampilan dan pengetahuan seseorang. Di Desa Jimbaran, Margorejo, Pati masih ada penduduk yang belum lulus SD. Hal ini mengindikasikan bahwa tingkat pendidikan di desa tersebut masih tergolong rendah. Sehingga sangat diperlukan penyuluhan untuk meningkatkan pengetahuan dan keterampilan masyarakat sekitar.

Kegiatan Kelompok Wanita Tani (KWT) Wijaya Kusuma Selama Ini

Kegiatan yang dilakukan oleh KWT Wijaya Kusuma selama ini hanya menanam ubi kayu di lahan yang mereka punya dengan bermodalkan keterampilan dan pengetahuan yang dimiliki. Sebagian besar masyarakat tidak ada inisiatif di dalam benaknya untuk melakukan perubahan terhadap produk yang 
akan dijual, misalnya pengolahan pasca panen. Hanya terdapat beberapa masyarakat saja yang berinisiatif untuk mengolah ubi kayu menjadi tepung tapioka sehingga nilai jualnya sedikit lebih tinggi.

Kegiatan yang dilakukan selama ini hanya berupa mengikuti sosialisasi yang diadakan oleh penyuluh pertanian, mengikuti arisan besama, dan sharing pengalaman mereka terkait pemelharaan lahan pertanian mereka. Anggota Kelompok Wanita Tani banyak yang idak aktif sehingga banyak sekali tujuan dari pembentukan Kelompok Wania Tani ini yang tidak tercapai.

\section{Dinamika Pemberdayaan Kelompok Wanita Tani (KWT) Wijaya Kusuma Tujuan Kelompok}

Tujuan program pemberdayaan merupakan gambaran tentang sesuatu hasil yang diinginkan oleh kelompok dapat dicapai melalui program pemberdayaan. Tujuan program pemberdayaan dalam penelitian ini dilihat dari penilaian responden terhadap kejelasan tujuan kelompok, pemahaman responden mengenai tujuan kelompok serta adanya kesesuaian antara tujuan individu dengan tujuan kelompok.

Hasil penelitian menunjukkan bahwa penilaian tujuan kelompok dalam kategori tinggi. Hal ini ditunjukkan dengan sebagian besar wanita tani mengetahui dan memahami tujuan kelompok. Berkaitan dengan program pemberdayaan berbasis pangan fungsional berbasis ubi kayu dan bandeng, tujuan yang ingin dicapai oleh kelompok antara lain peningkatan pemanfaatan ubi kayu dan bandeng sebagai sumber pangan dan gizi, berkembangnya usaha pengelolaan berbasis ubi kayu dan bandeng, serta peningkatan pendapatan dari usaha pembuatan olahan ubi kayu dan bandeng.

\section{Strukur Kelompok}

Struktur kelompok adalah bentuk tata huungan antara individu-individu dalam kelompok yang sekaligus menggambarkan kedudukan dan peran anggota dalam mencapai tujuan kelompok. Struktur kelompok dalam penelitian ini dilihat dari penilaian responden terhadap kejelasan struktur kelompok wanita tani, kejelasan peran pengurus, hak anggota dalam mengambil keputusan kelompok serta proses komunikasi dalam kelompok.

Hasil penelitian menujukkan bahwa penilaian struktur kelompok dalam kategori tinggi. Hal ini ditunjukkan dengan adanya struktur kepengurusan yang formal dan tetulis pada piagam pengukuhan kelompok oleh Kepala Desa. Pembina KWT dijabat oleh ibu Murti, Ketua dijabat oleh ibu Ramini, sekretais dijabat oleh ibu Ina Mursalun,dan bendahara dijabat oleh ibu Hidayanti. Adanya struktur kepengurusan juga sudah diimbangi dengan pembagian tugas yang jelas yang diberikan kepada masing-masing anggota.

\section{Pembinaan dan Pemeliharaan Kelompok}

Pembinaan dan pengembangan kelompok yang dimaksud dalam penelitia ini adalah upaya kelompok untuk tetap memeihara dan mengembangkan kehidupan kelompok. Pembinaan dan pemeliharaan kelompok pada penelitian ini diukur dengan indikator frekuensi pembinaan, peranan penyuluh pendamping, ketersediaan sarana serta upaya untuk mendapatkan anggota baru.

Hasil penelitian yang telah dilakukan menunjukkan bahwa pembinaan dan pemeliharaan kelompok termasuk kategori tinggi, artinya sudah ada usaha yang dilakukan oleh kelompok untuk mempertahankan kehidupan dalam kelompok. Usaha pembinaan dan pemeliharaan kelompok ditandai dengan adanya pertemuan rutin setiap bulan yang diselenggarakan oleh kelompok dan didampini penyuluh. Ketersediaan sarana 
prasarana dinilai sudah cukup lengkap. Alatalat yang dibeli oleh kelompok digunakan secara bersama-sama, tetapi anggota juga dapat meminjam. Sebagian besar kelompok telah menambah jumlah anggota sebagai upaya mengekalkan kelompok.

\section{Kekompakan Kelompok Selama Program}

Kekompakan kelompok yaitu rasa ketertarikan anggota terhadap kelompoknya. Kekompakan kelompok dalam penelitian ini diukur dengan frekuensi kerjasama kelompok, rasa solidaritas dan keesuain kebutuhan. Menurut Johnson dan Johnson (2012), situasi kerjasama menyebabkan tiap orang mempercayai dan menyukai satu sama lain, mau berkomunikasi secara efektif dan merespons dengan saling membantu keinginan, kebutuhan, dan permintaan.

Hasil penelitian dikatakan dapat sesuai ddengan teori di atas, kekompakan kelompok wanita tani disebabkan karena rasa nyaman antar sesama anggota dan intensitas komunikasi yang tinggi baik dalam kelompok maupun di luar kegiatan program. Solidaritas kelompok juga ditunjukkan dengan jawaban responden bahwa adanya kesediaan saling membantu apabila anggota lain mengalami kesulitan atau permasalahan. Hal ini disebabkan anggota berdomisili pada kawasan yang berdekatan sehingga sudah saling mengenal dan terjalin keakraban.

\section{Efektifitas Kelompok}

Efektifitas kelompok merupakan keberhasilan kelompok untuk mencapai tujuannya yang dapat dilihat pada tercapainya keadaan atau perubahan (fisik dan non fisik) yang memuaskan anggotanya. Efektifitas kelompok dalam peneitian ini diukur dengan penilaian keberhasilan kelompok dan manfaat yang dirasakan oleh anggota. Sebagian besar responen menyatakan bahwa masih kurang merasakan manfaat berupa terlatih bekerjasama dan meningkatkan jaringan. Manfaat non fisik yang dirasakan anggota baru sebatas peningkatan pengetahuan dan keterampilan pengolahan produk pagan berbasis ubi kayu dan bandeng.

\section{Partisipasi Anggota Kelompok Wanita Tani (KWT) Wijaya Kusuma Partisipasi dalam perencanaan}

Partisipasi adalah suatu keterlibatan mental dan emosi serta fisik peserta dalam memberikan respon terhadap kegiatan yang melaksanakan dalam proses belajar mengajar serta mendukung pencapaian tujuan dan betanggung jawab atas keterlibatannya. Partisipasi masyarakat sasaran yang merupakan anggota dan pengurus Kelompok Wanita Tani (KWT) Wijaya Kusuma dalam perencanaan dapat dilihat dari peranan anggota dalam rapat, frekuensi kehadiran dalam rapat, keaktifan mengemukakan idea tau usulan dan keaktifan mengajukan pertannyaan serta menanggapi pernyataan. Dari 25 anggota dan pengurus Kelompok Wanita Tani (KWT) Wijaya Kusuma yang ada, sebanyak 21 orang hadir mengikuti kegiatan penyuluhan. Hal ini menandakan bahwa partisipasi masyarakat dan antusiasme masyarakat tinggi. Sedangkan ketika dilaksanakan penyampaian materi, sebanyak 21 orang tersebut sangat antusias dan banyak yang bertanya terkait program yang diajarkan.

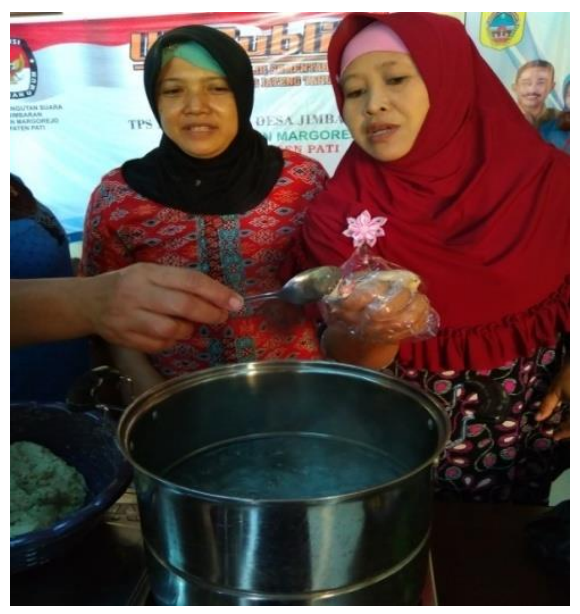

Gambar 1. Pelatihan pembuatan BAKAMBU Partisipasi Dalam Pelatihan 
Kelompok Wanita Tani Desa Jimbaran, Margorejo, Pati ketika dilakukan kegiatan pelatihan sangat aktif dan sangat antusias untuk mengikuti praktik pembuatan BAKAMBU, PUKEPO, dan DOKEPO aneka rasa. Mereka juga aktif berdiskusi dan sharing mengenai pengalaman mereka ketika membuat produk berbasis ubi kayu dan bandeng.

\section{Partisipasi Dalam Pemantauan dan Evaluasi}

Partisipasi pada tahap pemantauan dan evaluasi yaitu keikutsertaan wanita tani dalam memberikan tanggapan dan penilaian dari kegiatan kelompok wania tani. Diihat dengan keaktifan memberikan saran atau masukan, kehadian dalam kegiatan monitoring dan evaluasi dan penilaian terhadap hasil kegiatan. Partisipasi wanita tani pada tahap pemantauan dan evauasi teroong renah yang ditunjukkan dengan sebagian besar responden yang jarang memberikan saran atau masukan terkait keberjalanan program.

\section{KESIMPULAN}

Kelompok Wanita Tani yang kebanyakan berusia di antara 39 sampai dengan 52 tahun meningkat pengetahuan dan keterampilannya dalam mengolah makanan setelah dilakukan penyuluhan dan pelatihan. Kegiatan Kelompok Wanita Tani yang selama ini hanya menanam ubi dilahan yang dimilikinya sekarang sudah ada yang beralih untuk mengolah ubi kayu dan bandeng menjadi olahan pangan fungsional.

\section{DAFTAR PUSTAKA}

Alvin, Arifin et all. 2014. Pengaruh Pemberdayaan dan Motivasi Terhadap Kinerja Karyawan. $J$ Administrasi Bisnis 8(2): 3-13

Dewanti, Ratih dan Sudiyono. 2017. Pemberdayaan Anak Panti Asuhan AnNahl dan Yaumiha di Kabupaten Sragen Melalui Keterampilan Beternak Ayam Ras Petelur. J SEMAR 6(2): 67-77

Huraerah dan Purwanto. 2006. Dinamika Kelompok Konsep dan Alikasi. Bandung: Refika Aditama

Johnson, David dan Johnson, Frank. 2012. Dinamika Kelompok. Jakarta: PT Indeks

Kartono, Kartini. 2002. Psikologi Sosial untuk Manajemen Perusahaan dan Industri. Jakarta: Rajawali Press

Statistik Budidaya. 2014. Direktorat Perikanan Budidaya. Jakarta: Kementerian Kelautan Perikanan

Tarjana, Sri et al. 2011. Pergeseran Paradigma Pembangunan Pemberdayaan Perempuan Menuju Pengarusutamaan Gender. Surakarta: Cakra Books

Wijayakusuma, Hembig. 2010. Kajiam Sistem Mudulur Pada Usaha Tani Ikan Bandeng (Channos chanos, Forskal) di Sulawesi Selatan.J Pengkajian dan Pengembangan Teknologi Pertanian 5(7): 187-192 